\title{
Gender Equality: Women in Agriculture or Gender in Agriculture
}

\author{
Chekene $\mathrm{MB}^{1 *}$ and Kashim IU ${ }^{2}$ \\ ${ }^{1}$ Department of Agricultural Technology, Federal Polytechnic Bali, Nigeria \\ ${ }^{2}$ Department of Science Laboratory Technology, Federal Polytechnic Mubi, Nigeria
}

Submission: November 09, 2017, Published: December 05, 2018

"Corresponding author: Chekene MB, Department of Agricultural Technology, Federal Polytechnic Bali, Nigeria

\begin{abstract}
Creating interest and excitement around gender study has become an important part of agricultural development. Women in agricultural extension has established in Nigeria to increase the voice and share of women in agricultural sector. Unfortunately this development resulted to gender bias. This paper, the authors review the evidence that is in public domain in relation to limitation of WIA in access to resources, cultural belief and tradition of the societies. It has been found that the women in agricultural approach resulted to gender bias and promotes gender inequality. Therefore, this approach should change with a policy that will promotes gender equality. Like Gender and Development (GAD) approaches. Policy makers and researchers should serve as tools in promoting gender and development approach and the implication of the program (WIA) that support gender bias are; it brings conflict, affect societies cultural belief and tradition and also will resulted to total rejection of the program in some areas which may cause a serious problem to agricultural development in the country.
\end{abstract}

Keywords: Women in agriculture; Gender and development; Gender equality

Abbreviations: GAD: Gender and Development; ADP: Agricultural Development Programme; WIA: Women in Agricultural Extension; ICWR: International Centre for Research on Women

\section{Introduction}

Gender equality has a strong anxiety to the world and their interest was to address differences between man and women in terms of needs and responsibilities. In their effort to achieve this in Nigeria, government established Women in Agricultural extension (WIA) programme by the federal ministry of agriculture and World Bank and put it under agricultural development programme (ADP) so that they will help women in accessing the agricultural information, resources and reduce gender discrepancy level [1]. This approach also called women in Agriculture (WIA). With this, Agricultural development programme is facing a serious challenges of gender inequality and their main problem is poor understanding of what gender means. Gender is a principal organiser and controller of activities between people in Agricultural production, reproduction, distribution and consumption [2]. It also means roles and responsibilities and it depends on the cultural belief of the society giving to man and woman. Inability to understand gender may result to gender blindness and increases gender differences. Good Understanding of Gender will help programme planners and policy makers in agricultural development to achieve their objectives. Gender did not mean men or women rather how they associate. Gender is a social practice, idea and attributes giving to male or female [3].

\section{Gender analysis}

The gender analysis is a systematic way of gathering facts on gender inequality and its relationship with the aim of understanding and redresses the differences [4]. Gender study is to examine the interaction between men and women's role, right and responsibility as they have differences in their performance such as knowledge, needs, want, talent and experience [5]. In agricultural system, Gender analysis gives an in-depth knowledge on how to characterise the roles and responsibilities between men and women in production and processing [6]. Gender study may analyse the role and responsibility and find the best role for man or woman. For instance, women are characterising more peaceful and honest than men [7]. However, giving more emphasis on women desirable character may result to gender bias [8]. Gender analysis is associated with many factors such as class, age, sex, race, culture, belief, region, and political interest $[9,10]$. The objective of this work was to review the Women in Agriculture (WIAE) and suggest the best way for policy makers, project planners and programme leaders.

\section{Women role in agricultural development}

The contribution of women to agricultural development will not be overemphasis. Women provide $60-80 \%$ of food and more 
than half of the global foods are supply by the women [11]. Women spend $85-90 \%$ of labour force on household food processing and preparation [12]. Time allocation study found that women labour is highly significant than man [13]. Moreover, girls do more work in household than boys [14]. Again $60-90 \%$ of total farm work is done by women [15]. These covered wide range of activities such as land clearing, tilling, weeding, planting, and application of fertilizer, harvesting, threshing, winnowing, milling, transporting and marketing among others. Despite these facts, agricultural and economic policies give less priority to female [16]. In Africa if gender equality been adopted properly it may result to $20 \%$ $30 \%$ ) increase in yield output and $2.5-4.0 \%$ increase in global yield and this will alleviate global hunger by $12-17 \%$ [17].

In Nigeria, women have done a lot to agricultural development. They contribute up to $90 \%$ of agricultural workload $[18,19]$. Women provide $80 \%$ labour in agricultural marketing and processing activities and up to $70 \%$ of small scale agro-business [20]. Despite roles play women have been neglected in decision making and agricultural policies [21]. The roles of women have been stagnated by lack of extension information [22]. These are among the reasons why Nigeria government initiated women in agricultural extension programme (WIA) so as to increase the voice of women in agricultural sector [23]. In the other hand, women in agriculture approach considered only women and its effort was to increase the level of women participation in decision making and natural resource management (Gender and Agriculture n.d). This approach will stagnate gender issue because it concentrates on women [24]. Meanwhile, we cannot separate women from men in agricultural activities. Women work together with men in division of labour. For example, men perform hard work (cutting trees, making ridges) while women involved in planting of seed, harvest, transporting goods, processing and marketing [25]. Women and men together give an important contribution to agricultural development [26]. Considering only women may lead to gender bias. Any gender inequality in resource and economic opportunities will increases the level of poverty [27]. The WIA approach does not consider multiple roles of men in women empowerment [5]. This attracts new challenges to gender equality. In addition, women in agricultural extension (WIA) programme has shortage of women extension staff this resulted to difficulty in accessing their clienteles and most of the staff of WIA are not an agricultural extension expert and also, they lack ADP supports do to their gender bias [3].

\section{Access to resources and WIA}

The land is one of the most important resources in agricultural development while WIA programme did not consider land as a problem in which land access is a major problem to women in an agricultural society as women need basic resources for agriculture [19]. Women were experiencing difficulty in accessing land in Nigeria [28]. In the study of Socio-economic factors influencing rice production among male and female farmers in Nigeria found that accessing land is difficult to women in rice production [29]. again in the study of determining technical efficiency of NERICA rice production, the gender approach found that women have difficulty in accessing the resource than men, more especially credit and land [30]. Women are accessing land through their men in most part of Nigeria and in accessing credit land may serve as a good collateral and women lack land for collateral [31]. Further more women in developing countries were experiencing a problem in accessing land. For example, Santal women in Indian perceived owning land is a taboo, to the extent that women do not inherit land due to respect to their cultural belief and women embrace this culture so as to retain their identity as a good women "Good women do not inherit land" Book title [32]. However, methods of acquiring land are diverse between man and woman [Doss et al., 2011). In Uganda majority of women engage in joint ownership of land with their husbands but only few of them have the formal document of their land and even within those that have the formal document very few were women with less control over the land [33].

\section{Cultural belief}

The WIA approach did not consider the culture and belief of society in a wider context. Cultural attached and belief of some part of Nigeria may not tolerate the programme that comes with woman's agenda. Culture and traditional belief and family resistance were the major problems of woman's farmers [34]. Taboo is related to agricultural activities (from cropping to animal rearing), religion and culture has strong attached to agricultural production system [28]. Religion and cultural value affect woman that does not belong to any group in accessing agricultural information [31]. Even a nation with the same belief they live and understand things differently. For instance, in Afghanistan Sunni women are more restricted than Shi'as women [35]. Meanwhile, this situation is commonly happening in Nigeria whereby northern women are more restricted than the women in the southern part of the country.

\section{Gender and development approach (GAD)}

The gender and development (GAD) give emphasis on both men and women and how they interact to one another [36]. This will reduce gender inequality, promote gender equality, power relation and brings solution to developmental problems [37]. This approach (GAD) considered gender at the centre focal point of development and its gender related approach [38]. This approach addresses women that experience restrictions in accessing resources, empowerment and participation through equal treatment given to all [39]. Gender and development consider both men and women address inequalities that prevent development, and this commitment will be sustainable for future [5]. Holistic approach of GAD has impact on developmental agenda in many sectors [36,40-44]. Therefore, Agricultural production system may find it difficult to separate woman from man [45-51].

\section{Conclusion and Recommendation}

In conclusion, gender and development (GAD) approach is more compactable and respectful to people's culture, belief, norms, value and it's socially related approach as it considers who deserves the roles and responsibilities among peoples in an 
agricultural system. The gender and development approach is more important in addressing gender related issue than women in agricultural approaches as it redress the developmental issues between man and women this will stabilise the relationship in decision making, access to resources, division of labour and respect to people's belief and tradition while Women in agriculture (WIA) consider only women in their programme and this may promote gender bias. The study recommended that:

A. The project planners and researchers should consider the gender equality in resource access such as land, agricultural input and advisory services.

B. The government/private sector should promote gender and development approaches as they can't separate manwoman in agricultural system.

The policy makers should consider gender and development that respects belief, culture and tradition in their programme.

\section{References}

1. World Bank (2003) Nigeria: Women in agriculture, In: Sharing Experiences-Examples of Participating Approaches. The World Bank Group. The World Bank Participating Sourcebook, Washington, D.C, USA.

2. FAO (2006) Building on Gender, Agrobiodiversity and Local Knowledge. Training Manual. FAO, Rome, Italy.

3. Kingiri AN (2014) Comparative Strategic Behavior of Advocacy Coalitions and Policy Brokers: The Case of Kenya's Biosafety Regulatory Policy. Journal of Comparative Policy Analysis: Research and Practice 16(4): 373-395.

4. Reeves H, Barden S (2000) Gender and development: Concept and definition (DFID). p. 40.

5. UNESCO (2003) Gender mainstreaming implementation framework. Baseline definitions of key concepts and terms. p. 3.

6. Doss C (2013) Data Needs for Gender Analysis in Agriculture. International Food Policy Research Institute Discussion Paper 01261. Washington, USA, p. 22.

7. Cornwall A, Harrison E, Whitehead A (2007) Gender myths and feminist fables: the struggle for interpretive power in gender and development. Development and Change 38(1): 1-20.

8. Davids T, van-Driel F, Parren F (2014) Feminist change revisited: gender mainstreaming as slow revolution. Journal of International Development 26(3): 396-408.

9. Phoenix A, Pattynama P (2006) Intersectionality. European Journal of Women's Studies 13(3): 187-192.

10. Davis K (2008) Intersectionality as buzzword; A sociology of science perspective on what makes a feminist theory successful. Feminist Theory 9(1): 67-85.

11. Mehra R, Rojas MH (2008) A Significant Shift: Women, Food Security and Agriculture in a Global Marketplace. International Centre for Research on Women (ICWR).

12. Fontana M, Natali L (2008) Gendered patterns of time use in Tanzania: Public investment in infrastructure can help? Paper prepared for the IFPRI Project on 'Evaluating the Long-Term Impact of Gender-focused Policy Interventions. p. 59.

13. Budlender D (2008) The statistical evidence on care and non-care work across six countries. Geneva: United Nations Research Institute for Social Development (UNRISD), USA, p. 61.
14. Sharma S, Nagar S, Chopra G (2007) Household responsibilities of adolescent girls in Kangra and Kullu Districts in Himachal Pradesh. The Anthropologist 9(3): 199-201.

15. Damisa MA, Yohanna M (2007) Role of rural women in farm management decision making process: Ordered probit analysis. Trends in Applied Science Research 2(3): 241-245.

16. Fabiyi EF, Danladi BB, Akande KE, Mahmood Y (2007) Role of Women in Agricultural Development and their constraints: A Case Study of Biliri Local Government Area, Gombe State, Nigeria. Pakistan Journal of Nutrition 6(6): 676-678.

17. FAO (2010) Roles of women in agriculture. Prepared by the SOFA team and Cheryl Doss. Rome, Italy, p. 160.

18. NAERLS (2000) An assessment of contribution of women to family farming in north- eastern Nigeria. Report of a research sponsored by the National Agricultural Research Programme, Abuja, Nigeria. National Agricultural Extension and Research Liaison Service, Ahmadu Bello University, Zaria, Nigeria.

19. Ogunlela YI, Aisha AM (2009) Gender Issues in Agriculture and Rural Development in Nigeria: The Role of Women. Humanity \& Social Sciences Journal 4(1): 19-30.

20. Auta SJ (2004) Performance of Women Groups in Agricultural Activities in Kaduna State. Unpublished Ph.D Thesis, Department of Agricultural Economics and Rural Sociology, Ahmadu Bello University, Zaria, Nigeria.

21. Afolabi MM (2008) Women as pillars of national economy in Nigeria: A study of economic activities of rural women in six local government areas of Ondo State. IAFFE summer conference, International Association for Feminist Economics, Toronto, Italy, $19^{\text {th }}$ June -21 th July. p. 14.

22. Charles A, Willem Z (2008) Participation in Agricultural Extension, The World Bank participation sourcebook, Appendix II, Working Paper Summaries.

23. Tologbonse EB, Jibrin MM, Auta SJ, Damisa MA (2013) Factors influencing participation in women in agriculture (WIA) programme of Kaduna state agricultural development project, Nigeria. International Journal of Agricultural Economics and Extension 1(7): 47-54.

24. Jackson C (1996) Rescuing Gender from the Poverty Trap. World Development 24(3): 480-504.

25. Lawanson OI (2008) Female labour force participation in Nigeria: 'Determinants and Trends', Oxford Business and Economic Conference Program, Oxford, United Kingdom. pp. 1-27.

26. Sharon BH (2008) Rural Women and Food Security' FAO Participation in Panel Discussion on the occasion of the International Day of Rural Women held in New York, USA.

27. World Bank (2009) The Food and Agriculture Organization of the United Nations (FAO) and the International Fund for Agricultural Development (IFAD). Women in Agriculture Sourcebook.

28. Oladejo JA, Olawuyi SO, Anjorin TD (2011) Analysis of Women Participation in Agricultural Production in Egbedore Local Government Area of Osun State, Nigeria. International Journal of Agricultural Economics and Rural Development 4(1): 1-11.

29. Ayoola JB, Dangbegnon C, Daudu CK, Mando A, Kudi TM, et al. (2011) Socio-economic factors influencing rice production among male and female farmers in Northern Guinea Savannah Nigeria: lessons for promoting gender equity in action research. Agriculture and biology Journal of North America 2(6): 1010-1014.

30. Ojehomon VET, Ayinde OE, Adewumi MO, Omotesho OA (2013) Determinant of technical efficiency of new rice for Africa (NERICA) production: gender approach. Ethiopian Journal of Environmental Studies and Management 6(5): 435-460. 
31. Sulo T, Koech P, Chumo C, Chepng'eno W (2012) Socioeconomic factors affecting the adoption of improved agricultural technologies among women in marakwet country Kenya. Journal of Emerging trends in Economics and Management Science 3(4): 312-317.

32. Rao N (2008) Good Women do not Inherit Land: Politics of Land and Gender in India, Social Science Press and Orient Black swan, New Delhi, India, pp. 356.

33. Doss C, Truong M, Nabanoga G, Namaalwa J (2011) Women, Marriage, and Asset Inheritance in Uganda. Working Paper 184. Chronic Poverty Research Centre. Manchester, UK, p. 31.

34. Butt TM, Hassan ZY, Mehmood K, Muhammad S (2010) Role of rural women in agricultural development and their constraints. J Agric Soc Sci 6(3): 53-56.

35. Srinivas T, Malika A, Aden A, Rishkowsky B, Tibbo M, et al. (2013) Gender roles in Agriculture: the case of Afghanistan. Indian Journal of studies 20(1): 111-134.

36. IFAD (2000) International Fund for Agricultural Development. Gender Perspective: Focus on Rural Poor. An overview of gender issues in IFAD-assisted projects. IFAD, Rome, Italy.

37. Nyamu CI (2000) How human right and development should responds to cultural legitimization of gender hierarchy in developing countries. Harvard International Journal 4(2): 381-418.

38. Bradshaw S, Castellino J, Diop B (2013) Women roles in economic development: overcoming the constraints. Sustainable Development Solution Network, United Nation.

39. Nasiciso V, Henriques $P$ (2010) Women and land in Timor-Leste: issue in gender and development. Indian Journal of Gender Studies 17(49): 59-72.

40. Abdoulaye T, Amaza PS, Olanrewaju AS, Ellis-Jones J (2012) Promoting the adoption of innovation through participatory approaches. Example from the northern Nigeria. Tropicultura 30(3): 155-160.

41. Beaman L, Dillon A (2012) Do Household Definitions Matter in Survey Design? Results from a Randomized Survey Experiment in Mali. Journal of Development Economics 98(1): 124-135.
42. Bomuhangi A, Doss C, Meinzen-Dick R (2011) Who Owns the Land? Perspectives from Rural Ugandans and Implications for Land Acquisitions. Feminist Economics 20(1): 76-100.

43. Damisa MA, Samandi JR, Yohanna M (2007) Women Participation in Agricultural Production: A probit analysis. Journal of Applied Sciences 7(3): 412-416.

44. Davids T, van Driel F (2005) The Gender Question in Globalization: Changing Perspectives and Practice. Centre for International Development Issues, Netherlands, pp. 246.

45. Deere CD, Alvarado GE, Twyman J (2010) Poverty, Headship, and Gender Inequality in Asset Ownership in Latin America. Working Paper 296. East Lansing, MI, US: Centre for Gender in Global Context, Michigan State University, p. 35.

46. Fisher M, Reimer JE, Carr E (2010) Who Should Be Interviewed in Surveys of Household Income? World Development 38(7): 966-973.

47. Cecile Jackson (2003) Gender and Agriculture: unlocking African potential. A case of Nigeria: giving voices to women farmers. J of Agrarian Change 3(4): 453-480.

48. Odebode SO (2008) Appropriate Technology for Cassava Processing in Nigeria: Users Point of View. Journal of International Women Studies 9(3): 269-283.

49. Odurukwe SN, Matthews-Njoku EC, Ejioku-Okereke N (2006) Impacts of the women-in-agriculture (WIA) extension programme on women's lives: implications for subsistence agricultural production of women in Imo State, Nigeria. Livestock Research for Social Development 18(2): 301-314.

50. Peterman A, Quisumbing AR, Behrman J, Nkonya E (2011) Understanding the Complexities Surrounding Gender Differences in Agricultural Productivity in Nigeria and Uganda. Journal of Development Studies 47(10): 1482-1509.

51. Quisumbing AR (1996) Male-female differences in agricultural productivity: methodological issues and empirical evidence. World Development 24(10): 1579-1595.

\section{Your next submission with Juniper Publishers will reach you the below assets}

- Quality Editorial service

- Swift Peer Review

- Reprints availability

- E-prints Service

- Manuscript Podcast for convenient understanding

- Global attainment for your research

- Manuscript accessibility in different formats

( Pdf, E-pub, Full Text, Audio)

- Unceasing customer service

Track the below URL for one-step submission https://juniperpublishers.com/online-submission.php 